\title{
Gender Jihad: Muslim Women, Islamic Jurisprudence, and Women's Rights
}

Melanie P. Mejia

\section{Introduction}

$\mathrm{M}$

uslim women's rights have been a topic of discussion and debate over the past few decades, and with a good reason. Islamic Law (Shariab) is considered by many as patriarchal and particularly oppressive to women, and yet there are also others-Muslim women-who have rigorously defended their religion by claiming that Islam is the guarantor par excellence of women's rights. A big question begs to be answered: is Islam particularly oppressive to women?

The Qur'an has addressed women's issues fourteen hundred years ago by creating certain reforms to improve the status of women; however, these reforms do not seem to be practiced in Muslim societies today. ${ }^{1}$ How is this so? I contend that Islam, as revealed to Muhammad, is not oppressive to women; rather, its interpretation, in so far as it is enacted in the family laws and everyday living, is patriarchal and hence needs to be examined. ${ }^{2}$ The goal of this work is to discuss what the Qur'an says about certain problems which gravely affect Muslim women, specifically:

1. gender equality

2. polygamy

3. divorce and the concept of nushur.

Veiling, though it is one of the common topics in Muslim women's studies, is not included for the simple reason that the aforementioned topics

${ }^{1}$ See Azizah al-Hibri, “A Study of Islamic Herstory: Or How Did We Ever Get into this Mess?," Women's Studies International Forum, vol. 5 no. 1 (1982), 212-215.

2 The Arab conquests had a lot to do with this tendency towards a patriarchal understanding of the Qur'an. The broad Arabization and Islamization of the Middle East led into an integration of culture, customs and government. Iraq, the capital of the Muslim empire then, became a melting pot of Zoroastrians, Manicheans, Gnostics, Jews, pagans, Christians, etc. The fusion was from a large scale adoption of government and bureaucratic practice to the personal lives, practices and attitudes of individuals. This brought about misogynistic practices similar to the Greeks and the Byzantines. See Leila Ahmed, Women and Gender in Islam: Historical Roots of a Modern Debate (New Haven: Yale University Press, 1992). 


\section{GENDER JIHAD}

seriously encroach on Muslim women and bijab ${ }^{3}$, for whatever reason it is being worn, is ultimately a matter of choice.

Due to the recent historical events concerning the oppression of Muslim women "in the name of Islam," there is a need to go back to the source of Islamic belief in order to rediscover the Qur'anic position on Muslim women and their rights. The need for an immanent critique of the Shariah becomes more pressing than ever because of the negative interpretations of the West regarding Islam and its (the West) "messianic" obsession to free the woman (believed to be objectified as an other) from patriarchal institutionswhich is further exacerbated by the mistaken belief in feminist discourse that the only model of emancipation and empowerment is the Western type of feminism. ${ }^{4}$ However, we cannot just dispose of Islamic laws and opt for a more "modern" Westernized model because most Muslims are serious about their religion and prefer to solve the problem within the Muslim context. ${ }^{5}$ Islam is the basis of their identity and to discard it would risk alienating the majority of the Muslims and may only cause them to cling to Islam tenaciously. As long as Muslim women believe that their subjugation is divinely-decreed, they will hesitate to challenge the status quo-no matter how oppressive it may be. ${ }^{6}$

\section{Sources and Basic Principles of the Shariah ${ }^{7}$}

Muslim feminists point to the source of women's oppression to the Islamic laws; this is not surprising since almost every aspect of Muslim life relies on Shariah laws. Scholars based this jurisprudence on two aspects: religious and cultural. Jurists are a product of their culture and times; it cannot be helped if their interpretations become biased because they live in a certain Weltanschaunng. Islamic law, as we know it, is saturated with patriarchal

${ }^{3}$ Hijab refers to: a.) a simple headscarf; b.) what a Muslim woman wears in front of non-intimates, which consists of the following: a jilbab or a loose, opaque gown or dress which covers up to the ankles and a kbimar or head covering. In some cases, a niqaab or a face veil is added; c.) the way of dressing properly and modestly. For the Muslim feminist, the hijab means a lot of things; see Rachel Woodlock, Muslim Feminists and the Veil: To Veil or Not to Veil-is that the question, <http://www.maryams.net/articles_veil01>.

${ }^{4}$ Ibid.

${ }^{5}$ Muslims are wary of adopting a westernized model since the West was not exactly successful in their attempt to emancipate women from patriarchy. Al-Hibri observes: "[The West] created 'super moms' who are eternally exhausted and turned female sexuality into a commodity,” Azizah al-Hibri, "Islam, Law and Custom: Redefining Women’s Rights," American University Journal of Law and Policy 12, no. 1 (1997), $<$ http://www.karamah.org/docs./au redefiningmwr.pdf> (02 December 02 2004).

${ }^{6}$ Azizah al-Hibri, "Deconstructing Patriarchal Jurisprudence in Islamic Law: A Faithful Approach," in Global Critical Race Feminism: An International Reader, ed. by Adrien Katherine Wing (New York: New York University Press, 2000), 221.

7 The literal meaning of the Shariah is "the road to the watering hole." The Shariah is the expression of God's guidance for humanity; it is a code of laws which the Muslims are to follow. See John L. Esposito, Islam: the Straight Path, 3rd ed.(New York: Oxford University Press, 1998), 78. 
interpretations that they have been legitimated and are usually taken for granted. This blurring between interpretation and authority seems to be an interesting hermeneutical issue; for most Muslims, these are no longer an interpretation of Islamic teachings, but an objective reading of the Qur'an. ${ }^{8}$ Although during the time of the prophet, the status of women improved, it did not last long. It is important to note that the influence of other cultures such as the Byzantine and the Persian empires, as well as customs in pre-Islamic society, led to the sudden turn towards patriarchy. ${ }^{9}$

\section{A. The Development of the Shariah}

Whereas Muhammad was the interpreter of the Qur'an and served as judged in the first umma, upon his death the responsibility fell into the ruling caliphs. The difficulties the caliphs encountered in interpretation and application were compounded by the Arab's rapid acquisition of vast foreign territories. When the Umayyads assigned Damascus to be the capital of the Muslim empire, they adopted the administrative machinery of the Byzantine rulers they had succeeded, which facilitated the infiltration of foreign concepts into the still-developing and essentially rudimentary apparatus of Islamic law. Part of the new administrative structure established by the Umayyads was the office of the qadi or the judge. ${ }^{10}$ "The qadi is the official representative of the caliph to provincial governments. He acts as the overseer; the qadi's job is to make sure that the government decrees are carried out and also to act as an arbitrator in disputes."11 In rendering a decision, Muslim judges relied on three things: the Qur'anic teachings, prevailing customary Arab laws in the region, and their own personal judgment. ${ }^{12}$ This suggested subjectivity in enacting the Shariab; the body of laws differed from one local to another, given the cultural diversity of the empire's provinces and the independent judgment exercised by the judges. Such a state of affairs could not satisfy the pious Muslims, whose aim was to establish a new life in accordance with a religious law willed by God and in consonance with the Prophet's intentions. In all matters, religious or social, the will of Muhammad must be determined and his actions must be followed as an example. Thus, Muslims referred to the Prophet's Companions to learn this will; these were people who lived their lives in his company, witnessed his actions, and heard his judgments. ${ }^{13}$ As long as one had a "Companion" at hand, one could learn from his/her reports what pious usage required and what the details of the divine law were. But after the passing of

8 Azizah al-Hibri, “An Introduction to Muslim Women's Rights,” Windows of Faith ed. Gisela Webb (Syracuse University Press, 2000)

$<$ http://www.karamah.org/docs/azizah introtomwr.pdf $>$ (02 December 2004).

${ }^{9}$ See al-Hibri, "A Study of Islamic Herstory: Or How Did We Ever Get into This Mess?," 208-212.

${ }^{10}$ Esposito, Islam: The Straight Path, 75.

${ }^{11} \mathrm{Ibid}$.

12 Ibid.

13 Ignaz Goldhizer, Introduction to Islamic Theology and Law, trans. by Andras and Ruth Hamori (Princeton, NJ: Princeton University Press, 1981), 37. 


\section{GENDER JIHAD}

the first generation, one had to content himself with the information passed by the previous generation. In this manner, the transmission of the Prophet's actions and saying continued. Conduct and judgment were considered correct if their legitimacy can be traced back to a Companion who could testify that they were in harmony with Muhammad's intentions.

The major development on Islamic jurisprudence took place in the Abbasid dynasty. The Abbasid caliphs were great patrons of Islamic learning. During this time, the study of the Qur'an, the example of the prophet and the Shariah flourished in a new batch of scholars (ulama) who sought to discover, interpret and apply God's will to everyday life. They strayed away from the Umayyad practice of rendering judgment based on personal opinion, but sought to develop a more objective and comprehensive code of laws, and designated the task of enforcing or applying these laws to judges. The consensus of jurists was also developed.

Critics of the Umayyad charged that the differing customary laws, coupled with caliphal decrees and personal opinions of the judges resulted in a confused and often contradictory body of laws. They argued that if all Muslims were bound to obey the Shariah, then the Shariah ought to be defined more clearly and uniformly. Legal scholars such as Abu Hanifa (d. 767), Malik ibn Anas (d. 796), Muhammad al-Shafii (d. 819), and Ahmad ibn Hanbal (d. 855) started to review the laws developed by the Umayyad dynasty in the light of the Qur'an.

The result was the emergence of four main schools of law in Islam: Hanafi, Maliki, Shafii, and Hanbali. Despite having common aims and goals, problems still arose because these schools were pitted against each other, which caused further divisions within the schools themselves. Although they shared one thing in common: their starting point in Islamic jurisprudence was the Qur'an and the example of the prophet. But where the Qur'an was silent, they relied on customary practice in the locale. Following the example of the prophet was introduced by a legal scholar, Malik ibn Anas (the founder of the Maliki school), who wrote the first compendium of Islamic law. Malik was a scholar of both tradition and law. His main treatise, Muwatta, is a collection of tradition and laws; its legal arguments are supported by citations from hadith and the Qur'an. But where differences existed, the local consensus of Medina was followed. ${ }^{14}$ In contrast, the younger class of scholars of Kufa led by Abu Hanifa and al-Shaybani relied on jurist opinion and local law. ${ }^{15}$

By the end of the eighth century, Muslims were at a difficult position: despite their earnest efforts to bring uniformity to the Shariah, they were unsuccessful, considering the various schools of law, differing opinions, difference of cultural setting, and diversity of legalistic techniques employed. From this, two main positions emerged: those who wished to bring uniformity to the law by restricting the use of reason and relying primarily on the traditions of Muhammad versus those who vigorously asserted their right to

\footnotetext{
${ }^{14}$ Ibid., 77.
}

15 Ibid. 
reason for themselves in the light of such criteria such as equity or public interest. ${ }^{16}$ Muhammad ibn Idris al-Shafii (d. 819) resolved this problem by formulating a fixed methodology for all schools of law. Al-Shafii studied jurisprudence with Malik ibn Anas in Medina. He spent most of the early part of his career traveling through Iraq and Syria, familiarizing himself with legal schools before settling in Egypt. Al-Shafii's major contribution to Islam was the establishment of four sources of law:

1. The Qur'an

2. Example of the prophet (Sunnab)

3. Consensus (ijma) of the community

4. Analogical reasoning or deduction (Qiyas)

Al-Shafii taught that there were only two material sources of law: the Qur'an and the Sunnah, which is preserved in the hadith collections. However, the example of the prophet here does not point to all of his actions, but only those which are divinely inspired and no longer with tribal custom. ${ }^{17}$ Another innovation of al-Shafii is that he transferred the authority for legal interpretation from individual law schools to the consensus of the community, basing this from the hadith where Muhammad once said, "My community will not agree upon an error."18 This became the third source of law: consensus (ijma). Personal reasoning was also restricted; where there is no explicit revealed text or consensus from the community, the judges cannot rely on personal judgments concerning new problems that emerged in the community. Instead they were to use analogical reasoning (qiyas), to seek for a similar or analogous situation in the Qur'an and apply it to the existing problem. Deductive reasoning, according to al-Shafii, will eliminate the arbitrary nature of legal reasoning prevalent in the more inductive approach of those who relied on their personal judgment. ${ }^{19}$

\section{B. Sources of the Shariah}

\section{The Qur'an}

The Qur'an is the core of Islamic law, which is the literal word of God revealed to Muhammad over a period of 22 years (610 AD-632 AD) through the angel Gabriel to guide mankind. Being the word of God, it is eternal and immutable. Although the Qur'an is the foundation of Islamic law, it does not constitute a comprehensive code of laws. ${ }^{20}$ It comprises of general and specific laws, the general being far more numerous than the latter. The specific rules tend to deal with matters of worship or with matters relating to family,

\footnotetext{
16 Ibid.

${ }^{17}$ Ibid., 78.

${ }^{18}$ Ibid.

${ }^{19}$ Ibid.

${ }^{20}$ Esposito, Islam: The Straight Path, 79.
} 


\section{GENDER JIHAD}

commercial or criminal law. ${ }^{21}$ Since most are general laws and legal prescriptions, they require interpretation before they can be applied in a specific situation or context.

\section{Sunnah of Muhammad}

When the Qur'an is vague on a certain topic or does not say anything on it, scholars turn to the Sunnah for further clarification and guidance. The Sunnah is comprised of the Hadith and examples of the Prophet as recorded by his companions and those who were close to him during this time. The importance of Sunnah is based on the Qur'anic verse:

O ye who believe! Obey God, and obey the Apostle, and those charged with authority among you. If ye differ in anything among yourselves, refer it to God and His Apostle. ${ }^{22}$

To emphasize the significance of the Qur'an during the early days of revelation, Muhammad forbade the recording of his actions and sayings other than the Qur'anic revelations. ${ }^{23}$ It was not until the Abbasid period that Muslim scholars started to collect sayings from the prophet. To avoid pious fabrications by those who believed that their practices were in congruence with the teachings of Islam and those with political agendas, a science of determining the validity and authenticity of ahadith was developed. These evaluations focused on two criteria: the chain of narrators (isnad) and subject matter (matn). ${ }^{24}$ For a hadith to be considered authentic, the biographical information of the narrator must be traced and his relation to the prophet. Not only must the experts have to record the hadith as faithfully as possible, they also have establish its isnad, the chain of people who transmitted it from its source, its source being a Companion of the Prophet who had heard it said or seen it done. ${ }^{25}$ The important points were: the person's proximity to the Prophet, his or her personal qualities, and especially the reputation for giving a good memory for not recounting just anything. ${ }^{26}$

Aside from tracing the isnad of a certain hadith, the meaning and content (matn) of the hadith must not contradict the teachings of the Qur'an. A well-known hadith by Muhammad states:

\footnotetext{
21 Azizah al-Hibri, Islamic Constitutionalism and the Concept of Democracy,

<www.karamah.org/docs.azizah islamic constitutionalism.pdf $>$. Cf. Abd al-Hamid Mutawalli, Mabadi Nizam al-Hukm Fi'l Islam (Alexandria 2nd ed., 1974), 34-46.

${ }^{22}$ Qur'an 4:59.

23 Azizah al-Hibri, Islamic Constitutionalism and the Concept of Democracy.

${ }^{24}$ Esposito, Islam: The Straight Path, 80.

${ }^{25}$ Fatima Mernissi, The Veil and the Male Elite: A Feminist Interpretation of Women's Rights in Islam ( Reading, MA: Addison-Wesley, 1991), 35. For a detailed discussion on the authenticity of ahadith see Goldhizer, 37-47.

${ }^{26} \mathrm{Ibid}_{\mathrm{s}}, 35$.
} 
After my death more and more sayings will be ascribed to me, just as many sayings have been ascribed to previous prophets (without their having really said them). When saying is reported and attributed to me, compare it with God's book (Qur'an). Whatever is in accordance with that book is from me. ${ }^{27}$

Stories concerning the behavior of the prophet are divided into the following categories: sound, good, acceptable, or weak. ${ }^{28}$ On the basis of the chain of narrators, abadith are classified from the point of view of narration as continuous (mutwatir), well-known (mashur) and isolated (abad). ${ }^{29}$ Muwatir refers to those traditions whose isnad is consistent and continuous. Mashur are traditions whose narrations could be traced back to one or two narrators or companions at the time of the prophet. And abad, the weakest among the three, refers to traditions whose chain of narrators was only limited to one authority. Mernissi notes that one of the reasons for the increase of fabricated hadith is because of the growing dissension in the early Islamic community after the death of Muhammad. ${ }^{30}$ This resulted to several civil wars and finally to a great schism between the Sunni and the Shiites. It should be remembered that Muhammad not only played the role of a spiritual leader for the Arab community but also as their political leader. It is easy to imagine that after his death, several individuals want to take his place by seeking legitimacy in and through the sacred text. Thus, the tension in the seventh century Islamic community: on the one hand there is desire of the male politicians to dominate the sacred and, on the other hand, the fierce determination of the scholars to oppose them through the elaborations of the figh (a veritable science of religion) with its concepts and its methods of verification and counter-verification. ${ }^{31}$ There were also some religious scholars who were willing to fabricate tradition for the sake of money. These fabrications are divided into several categories:

The first category is those who attribute to the Prophet remarks that he did not make. This category is subdivided into two groups: those who lie for material advantage and those who lie for ideological advantage. The second category is those who did not fabricate the content of the hadith itself, but simply falsified the chain

\footnotetext{
27 Goldhizer, 43-44.

28 Al-Hibri, Islamic Constitutionalism and the Concept of Democracy. Press, 1982), 6.

${ }^{29}$ John L. Esposito, Women in Muslim Family Law (Syracuse, NY: Syracuse University

${ }^{30}$ Fatima Mernissi, Women and Islam: A Historical and Theological Inquiry tr. Mary Jo Lakeland (New Delhi: Kali for Women, 1991), 36.

${ }^{31}$ Ibid., 43.
} 


\section{GENDER JIHAD}

of transmitters. For example, they attach onto a weak hadith a very authentic isnad, composed of famous persons. ${ }^{32}$

In the first category, the badith is composed of fictitious sayings attributed to Muhammad. "Muhammad said" in most cases means it is right, unquestionable, or a religiously unassailable fact. This is especially the case for those who wish to advance their political agenda. The second category is to connect a weak hadith, those with questionable isnad but nevertheless circulates within the community, to a chain of reputable persons. Of course, there are also those who simply lie; this individual claims to have heard remarks that he never really heard or to have met people he never really met. From the above details on the authenticity of hadith, we can conclude that these abadith are weak because: 1) they contain a number of transmitters who were single reporters ${ }^{33}$ and 2) all of the above abadith are weak because of the unreliability of transmitters. From the thousands of ahadith, purportedly about Muhammad, only six collections are considered authentic and authoritative, those of: Ismail al-Bukhari, Muslim ibn al-Hajjaj, Abu Dawud, al-Nisai, al-Tirmidhi and Ibn Maja.

\section{Analogical Reasoning (Qiyas) and Consensus (Ijma)}

Qiyas or legal reasoning by analogy is a restricted form of ijtihad. When faced by a new problem or issue, scholars resort to a similar situation in the Qur'an and the Sunnah. For example, jurists find a resolve to a problem by looking for a similar situation in the Qur'an and applying it on the new problem they are faced with.

Consensus is the fourth source of Shariah; it is derived from the prophet's saying, "My community will never agree on an error." 34 This began as a natural process of settling problems after the death of Muhammad, whereby the community follows the opinion of the public. However, this consensus soon changed into the consensus of Muslim scholars.

\section{Other Sources}

Other sources of Islamic jurisprudence include: custom, public interest and jurist preference. The general rule on this is that they are allowed as long as they do not contradict the Qur'an and the Sunnah. ${ }^{35}$ Here, it becomes clear that social aspects, such as culture and practice, play only a secondary role in the development of Shariah. A certain practice can be followed in so far as it

32 Mernissi, The Veil and the Male Elite, 45.

33 Al-Hakim Abu Abd Allah al-Naysaburi and Ibn Hajar al-Asqalani, eminent scholars of hadith, defined a sound (sabih) hadith as one that is related by a well-known Companion and transmitted by at least two followers, and reported by many narrators. See Hassan, 79 .

${ }^{34}$ Esposito, Islam: The Straight Path, 82.

35 Al-Hibri, Islam, Law and Custom: Redefining Women's Rights. Emphasis added. 
remains consistent with the basic teachings of Islam, otherwise it should be discarded in favor for an action that promotes Islamic principles.

C. Basic Principles of the Shariah ${ }^{36}$

Muslim jurists have agreed on a certain number of basic principles of Shariah.

\section{Change in Time, Place and Circumstance}

A major feature of Islamic jurisprudence is that its laws may change to adapt to the change of time, place and/or circumstance. Shari'ab recognizes the dynamism of societies; societies differ in place and time. Properly understood, this principle allows a mujtabid to analyze not only the meaning and significance of a specific verse in the Qur'an, but also the context in which it was revealed. It means that not all the verses in the Qur'an can be applied under all circumstances. There are ayab (equivalent to verses) that apply only to a specific context.

\section{Necessity/Avoidance of Harm}

This principle indicates a choice between two lesser evils. When faced with two evils, the Muslim must choose that which may bring lesser harm to others and the self. The school of Hanafi, for example allowed Muslims to eat pork and drink alcohol out of necessity. The Qur'an even states: But if one is forced by necessity, without willful disobedience, or transgressing due limits, then Allah is Oft-Forgiving, Most Merciful. (16:115). Necessity is used in a narrow way, meaning that God allows Muslims to eat pork or drink alcohol to save one's life.

\section{Cessation of Cause}

This principle is corollary to the principle of change in circumstance. Laws come into being out of a specific cause or necessity and when that cause is no longer existent, the law must also cease to exist. For example, the Qur'an (9:60) encouraged Muslims to give a portion of their donations for charity a certain group of Arabs called 'al-Mu'allafatu Qulububum.' This arose out of a need to strengthen the religion in the Arab region. However, when Islam became an established religion, caliph Umar saw that there is no need to continue with this law.

${ }^{36}$ For this part, the researcher mostly referred to al-Hibri's essay, Islamic

Constitutionalism and the Concept of Democracy,

$<$ www.karamah.org/docs.azizah islamic constitutionalism.pdf $>$. 


\section{GENDER JIHAD}

\section{Public Interest}

Islamic laws must be in accord with public interest and must be beneficial to the entire community. If they do not conform to this, they must be re-examined and reformulated for the benefit of the public. Furthermore, if the public interest changes, the laws must also change accordingly.

\section{Gradualism and Philosophy of Change}

Islam is not a religion of abrupt change. Proof of this is that the Qur'an itself was not revealed in a single instance to Muhammad, it was revealed within a period twenty-two years. It was revealed gradually to suit the needs and capabilities of the Arab society at that time.

Gradualism is an important feature in Islamic law. It applies to a lot of aspects but not to all. For example, the prohibition of alcohol was not imposed abruptly. ${ }^{37}$ During the pre-Islamic period, Arabs consumed considerable amounts of alcohol. Muhammad tried to curb this practice first by advising to limit the amount of alcohol intake. And then it changed to prohibiting alcohol during time of prayer until the ban became absolute. On the other hand, there was no gradualism on monotheism. The change from polytheism to monotheism is one of the core principles in Islam and cannot be applied to their philosophy of change.

On a pragmatic basis, sudden changes in law are also discouraged by jurists because it results in chaos and divisiveness among the people. ${ }^{38}$ This may be seen as an attempt to preserve the status quo and sudden changes result in compulsion which contradicts the doctrine of independence of faith.

\section{Three Problems}

We now turn to an analysis of the three problems selected in this paper.

\section{A. Gender Equality}

Patriarchal men point to a certain verse in the Qur'an to justify their position: "Men are qawwamün over women bima God faddala ba'd of them over others, and bima they spend of their own money ...."39

\footnotetext{
${ }^{37}$ See Qur'an 2:219, 4:43 and 5:90.

38 Al-Hibri, Islamic Constitutionalism.

${ }^{39}$ Qur'an 4:34. The researcher referred to Al-Hibri's translation on this. See Azizah Y. al-Hibri, "A Study of Islamic Herstory: Or How Did We Ever Get into this Mess?" Women's Studies International Forum 5/2 (1982), 217. See also, Azizah Y. al-Hibri, Islam, Law and Custom: Redefining Women's Rights, http://www.karamah.org/docs/au_redefiningmwr.pdf. Pickthall translated this verse as: "Men are in charge of women, because Allah hath made the one of them to excel the other, and because they spend of their property (for the support of women)."
} 
This verse has often taken to mean that men have authority over women because they are superior over women (physically and intellectually) and because they provide for the women. But there is no verse in the Qur'an that speaks of men being superior over men intellectually or physically. According to Al-Hibri, this is unwarranted and inconsistent with other Islamic teachings. ${ }^{40}$ It is necessary to make a linguistic analysis of this verse to find out what it means.

Qawwamün (sing. qawwam) has been translated variously to mean "head," "boss," "leader," "protector," or even manager," "guide," and "advisor." 41 One Arabic dictionary defined the root word, qiyam, as "having the meaning of preservation and betterment." 42 It can also be defined as "one who manages the people's affairs, leads and straightens them out." 43 These two definitions are not gender exclusive but are open to hierarchical authoritarian interpretations.

The verb faddala is usually translated as "being superior." 44 It is used to mean that there is a preference for one over the other, perhaps due to a feature that the other lacks. The word bima is a complex Arab word. It is composed of two root words, $b i$ and ma. Al-Hibri listed the meanings of $b i$ as: a) one that conveys a relation of causality; b) one which conveys circumstantial and; c) one which conveys a quantity which is less than all (some). ${ }^{45} \mathrm{Ma}$ acts as a pure connector. Taken in this way, the word bima could mean: a) because; b) in circumstances where and; c) in that which. Looking back at the verse from Qur'an 4:34, it can be re-translated as: Men are [advisors/guides] to women [because/in circumstances where/in that which] God made some of them different from some others and [because/in circumstances where/in that which] they spend of their own money.

To be a qawwamin, two conditions must be met: that the man must be someone God gave more in the matter at hand than the woman; and that he be her provider. Only under both of these conditions may the man presume to be qawwamin of the woman. ${ }^{46}$ The word $b a$ 'd means "some" and further underlines the meaning conveyed by bima, namely that qiwama applies only in certain cases and times when both conditions are satisfied. ${ }^{47}$ Understood this way, it would mean: in cases, where women know less than men and they are being provided for by their husbands/male guardians, men should guide the women. The first element is important for explaining why the advisory role is and the second element limits the advisory role of the man who is already

40 See al-Hibri, "A Study of Islamic Herstory: Or How Did We Ever Get into this Mess?" in Women and Islam, 217-219.

${ }^{41}$ Al-Hibri, Islam, Law and Custom: Redefining Women's Rights,

42 Ibid.

43 Azizah Y. al-Hibri, Qur'anic Foundations of the Rights of Muslim Women in the Twenty-First Century, <http:// www.karamah.org/docs/azizah quranicfoundationsofmwr.pdf > .

44 Ibid.

45 Azizah Y. al-Hibri, Islam, Law and Custom: Redefining Women's Rights.

${ }^{46}$ Amina Wadud, Qur'an and The Woman: Rereading the Sacred Text from a Woman's Perspective, 2nd ed. (New York: Oxford University Press, 1999), 70.

47 Al-Hibri, Qur'anic Foundations of the Rights of Muslim Women. 


\section{GENDER JIHAD}

taking care of the woman. In those circumstances, God gave the male the responsibility of offering the female guidance and advice in those areas in which he happens to be more qualified or experienced. This basically rules out the claim that men have authority over women in all matters, even in those that they are not qualified of. For only under extreme conditions (for example, insanity) does the Muslim woman lose her right to self-determination, including entering into any kind of business contract without permission from her husband. ${ }^{48}$ Moreover, if the above verse is read as men having authority over women, it would contradict the other verses in the Qur'an, particularly Surah 9:71 which states: "The Believers, men and women, are awilya (protectors) one of another." How can men be superior over women if men and women are supposedly protectors of one another? Interpreted in this way, Surah 4:34 could also imply that women can advise or handle the affairs of their husbands in matters where they are more qualified. For example, if the woman is a corporate lawyer and her husband is a businessman, clearly she is in a better position to give him legal advice. This conclusion is in line with the above verse that men and women are awilya (protectors) of one another.

Hierarchical logic was pushed to such an extreme that the laws were designed to ensure that society places the Muslim woman in a situation where the two Qur'anic conditions for her subordination would automatically be satisfied. ${ }^{49}$ This was done by denying her basic right to education and to work, which would make her financially independent from the male.

Such gender-biased argument employs Satanic logic. Satan's disobedience resulted from an arrogant believed that since he was created from fire while man was from clay, he is, therefore, superior than man. ${ }^{50}$ In refusing to bow to man, Satan committed the cardinal sin of shirk, the belief in more than one Supreme Being. ${ }^{51}$ Shirk is the opposite of tawhid, which is belief in one God. In opting for his hierarchical view, Satan chose to make his will supersede God's will. Muslims who are vain and arrogant--whether for individual, racial, economic or gender-related reasons-engage in Satanic logic. 52

\section{B. Polygamy}

According to Muslim tradition, a man may marry up to four wives at any given time. A woman, however, does not seem to have the same right. Muslims base their view concerning polygamy on the fact that Muhammad had a lot of wives during his lifetime..$^{53}$ We cannot conclude that just because Muhammad was polygamous during his life, all Muslim men are allowed to be such. It must be stressed neither Muhammad nor his wives are like other men

48 Al-Hibri, “A Study of Islamic Herstory," 218.

49 Al-Hibri, Qur'anic Foundations of the Rights of Muslim Women.

${ }^{50}$ Qur'an 7:11-15.

51 Al-Hibri, Qur'anic Foundations of the Rights of Muslim Women.

52 Al-Hibri, "Deconstructing Jurisprudence in Islamic Law," 226.

53 When Muhammad died, he left nine wives, not including his concubines. 
or women. ${ }^{54}$ Most of his marriages after Khadija's death were either to establish political ties with other tribes or to take care of women who were widowed by the war. ${ }^{55}$ One of the most often cited passage to justify polygamous practices is:

Marry women of your choice, Two or three or four; but if ye fear that ye shall not be able to deal justly (with them), then only one ... to prevent you from doing injustice. ${ }^{56}$

In order to understand this passage, the occasion in which the following verse was revealed must first be explained. This was revealed during the battle of Uhud in which there were a lot of casualties on the side of the Muslims as well as the Meccans and a lot of women were widowed and children were orphaned. ${ }^{57}$ It should be remembered that during the PreIslamic era, women were provided for by the tribe but this changed when the structural order was shifted to the family. Part of the above verse states:

And if ye fear that ye will not deal fairly by the orphans, marry of the women, who seem good to you, two or three or four . ....58

One solution suggested to prevent mismanagement was marriage to the female orphans but the Qur'an limited this number to four to balance to economic responsibility of maintaining the wife with access to the wealth of the orphaned female. ${ }^{59}$ However, this verse also says:

And if ye fear that ye cannot do justice (to so many) then one (only) or (the captives) that your right hands possess. Thus it is more likely that ye will not do injustice ....60

The second passage implies that man cannot be fair to women even if he tries hard. Being fair and just means that there is no preference over the other. When a man marries for the second time, there is a preference for the second wife. He married her precisely because the first wife is not enough.

Islam is so particular about justice that it does not allow one even to make a proviso on the occasion of the marriage contract. Even if we assume that a man is fair with his wives, it still would be difficult since the

${ }^{54}$ Qur'an 33:32; 33:50.

55Barbara Freyer Stowasser, Women in the Qur'an, Traditions and Interpretation (New York: Oxford University Press, 1994), 86-87.

56 Qur'an 4:3.

57 Qamaruddin Khan, Status of Women in Islam (Bangalore, India: Sterling Publishers Pvt. Ltd., 1990), 33.

${ }^{58}$ Qur'an 4:3.

${ }_{59}$ Wadud, 83.

${ }^{60}$ Qur'an 4:3. See also a similar passage, Qur'an 4:129. 


\section{GENDER JIHAD}

measurement of justice is not made clear although it is often understood as material, that the husband is able to provide the woman with all her needs. This would be the case if the woman is unemployed and would be considered a financial burden. However, in today's world it is no longer accepted that only men can work, do work, or be the sole provider of the family. Another rationale given for a man having more than one wife is centered on the woman who is unable to have children. ${ }^{61}$ There is no mention of this as a justification for polygamy in the Qur'an. Furthermore, there are a lot of orphaned Muslims and other children who would benefit from the love and care of childless couples.

If we apply basic Shariah principles, polygamy would be inconsistent for the following reasons: it harms Muslim women, and it does not promote public interest. Islamic laws must be in accord with public interest and must be beneficial to the entire community. ${ }^{62}$ If they do not conform to this, they must be re-examined and reformulated for the benefit of the public. A big percentage of the Muslim population comprises of women and such practice is unfair to them. It is harmful because not all women are given the attention that they deserve and they are not treated equally because of a preference over the other. Moreover, polygamy can only be practiced by those with financial capabilities. A poor man who can barely feed his family will not take another wife because he will have one more mouth to feed. Hence, it cannot be said that it promotes the public interest because it cannot be applied to everybody.

\section{Divorce and the Concept of Nushuz}

When the first ummah was established, Islam guaranteed women rights that they were denied during the Jabiliyab ${ }^{63}$ : the right to an education equal to that of the male, the right to financial independence and even the right to engage in ijtihad. It also viewed marriage as an institution in which human beings find tranquility and affection with each other. ${ }^{64}$ However because of hierarchical logic, Muslim women were denied their God-given rights. Principles meant to improve their status were interpreted in a misogynistic manner to favor men. Marriage, for example, was interpreted to favor men over women.

In many Muslim countries, women do not have the right to contract their own marriage. In these countries, a Muslim woman needs a guardian (wali) to contract the marriage on her behalf. 65 The principle behind this is

\footnotetext{
61 Wadud, 84.

62 Al-Hibri, Islamic Constitutionalism and the Concept of Democracy.

63 The term Jabiliyah, stemming from the Arab word jabl, meant ignorance and was used to describe the period prior to the birth of Islam. While some considered this an age of barbarism, it would be a grave mistake to think so, for the Arab society then was more advanced in terms of technology and commerce compared to other societies existing at that time. See AlHibri, “A Study of Islamic Herstory,” 208.

${ }^{64}$ Qur'an 30:21.

65 Al-Hibri, Islam, Law and Custom: Redefining Women's Rights.
} 
that Islam provides the young and inexperienced woman with additional safeguard, namely, an automatic consultative mechanism by which she could solicit advice from her father (or one who has a similar relation) about a prospective husband. ${ }^{6}$ However, this regulation is not supported by the Qur'anic prescription or Sunnah of the prophet. ${ }^{67}$

The role of the wali is advisory. However, some schools such as the Shafii, Maliki, and Hanbali interpreted this to mean that the guardian has the sole authority to contract a marriage for a woman. ${ }^{68}$ Even if the woman has a certain man in mind that she would like to marry, if the wali does not agree with it, there is nothing that she can do.

Women are also expected to obey their husbands unconditionally, and if she does not, the husband has the right to beat her. This is based on the following verse,

So good women are qanitat, guarding in secret that which Allah hath guarded. As for those whom ye fear nushur, admonish them and banish them to beds apart, and scourge them. Then if they obey you, seek not a way against them. ${ }^{69}$

The word qanitat used here is often misinterpreted to mean "obedient" and assumed to mean obedient to the husband. ${ }^{70}$ This word does not only appear in this verse nor does it pertain exclusively to females; it describes a characteristic or personality trait of believers towards Allah. ${ }^{71}$ Simply, believers (men and women alike) are qanitat because they are God-fearing beings. This is clearly distinguished from the concept of $t a^{\prime} a$, which indicates obedience between created beings. ${ }^{72} \quad \mathrm{Ta}^{\prime} a$ enables the husband to prohibit the woman from leaving her home, unless she is willing to risk loss of financial support and, in some cases, divorce. ${ }^{73}$ To require complete obedience to the husband would mean violating the essential principle of free will in Islam. Sayyid Qutb, in his work, explained that nushuz is a state of disorder between the married couple. ${ }^{74}$ In a state of disorder, the Qur'an suggests the following: ${ }^{75}$

${ }^{66}$ Al-Hibri, An Introduction to Muslim Women's Rights.

${ }^{67}$ John L. Esposito, Women in Muslim Family Law, 17.

68 Encyclopedia of Islamic Law: A Compendium of the Major Schools adapted by Laleh Bakhtiar (Chicago, IL: ABC International Group Inc., 1996), 423.

${ }^{69}$ Qur'an 4:34.

70 Wadud, 74. Even Marmaduke Pickthall translated the word as such.

${ }^{71}$ See Qur'an 33:35, 3:17 and 66:12.

72 Wadud, 74.

73 Al-Hibri, Islam, Law and Custom: Redefining Women's Rights.

${ }^{74}$ Wadud, 75. Some Muslim commentators explained that nushur means a refusal by the women to obey their husbands in matters of sex. Al-Tabari noted that: "Al-nushuz means that the wife treats her husband with arrogance, refuses to join him in the martial bed; it is an expression of disobedience (al-masiya) and an obvious unwillingness to carry out what obedience to the husband requires. It is way of showing hatred (bughd) and opposition (i'rad) to the husband." Mernissi, Women and Islam, 162.

75 Ibid. 


\section{GENDER JIHAD}

1. A verbal solution: whether between the husband and the wife (as stated in Qur'an 4:34; 4:128) or between the husband and the wife with the help of arbiters $^{76}$

2. If the open discussion fails, then a drastic solution is suggested: separation.

3. Scourging is permitted only under the extreme circumstances.

If there is a fight between the husband and the wife, Islam does not immediately suggest divorce. Rather, both parties are encouraged to work it out through an open discussion. This is the first and preferred solution by the Qur'an, because it is discussed in both instances of the word nushur: ${ }^{77}$ This is in line with the Qur'anic verse stating: "it is no sin for them twain if they make terms of peace between themselves. Peace is always better." 78

If it cannot be resolved by agreement, only then would it be recommended to separate. This does not connote a permanent separation, but rather merely suggests that the husband and the wife are not to sleep in a single bed. This becomes significant only if the husband and wife share the same bed, otherwise this would not be a meaningful measure. In addition, "beds apart" indicates at least a night of separation; this is a cooling-off period that would allow both the husband and the wife to reflect on the problem at hand. ${ }^{79}$

It is mentioned as a last resort that a husband may beat his wife. The original word in Arabic is daraba, which according to Lanes' Lexicon means "to strike" but it doesn't necessarily connote violence. ${ }^{80}$ Traditionalists and apologists address the criticism that this approach promotes wife-beating by arguing that there are limitations on when and how a husband can inflict corporal punishment on his wife. They argue that the physical punishment can only be resorted to when all other reasonable means of reprimanding the wife have been exhausted. Some traditionalists argue that a man may use physical force that does not amount to beating and bruising. For example, some scholars were of the view that a man could strike his wife with a toothbrush or even a folded handkerchief; the strike is a symbolic gesture of being reprimanded.

In light of the Qur'anic worldview that endorses equity, justice, harmony, and compassion, the meaning "to strike" cannot possibly fulfill the objective of protecting the institution of marriage and securing the physical and emotional integrity of women. In marriage there should be harmony ${ }^{81}$, love,

${ }^{76}$ Qur'an 4:35 states: And if ye fear a breach between them twain (the man and wife), appoint an arbiter from his folk and an arbiter from her folk. If they desire amendment Allah will make them of one mind.

77 Wadud, 75.

${ }^{78}$ Qur'an 4:35.

${ }^{79}$ Wadud, 76.

${ }^{80} \mathrm{Ibid}$.

${ }^{81}$ Qur'an 4:128. 
and mercy.82 Furthermore, husbands and wives should protect each other: "They (feminine plural) are raiment for you (masculine plural) and you are raiment for them." 83

Divorce is generally referred to as talaq, meaning "repudiation." Talaq comes from the root tallaqa meaning to release a human being from any obligation incumbent upon him. ${ }^{84}$ Every attempt should be made to maintain a marriage but once the marriage becomes a failure, Muslim law allows parties to separate from each other. It serves as a safety valve in cases where spouses no longer live in harmony and so the purpose of marriage would be defeated if they lived together. ${ }^{85}$ However, its use has been distorted to give sole access to repudiate the woman at any time. Unlike women, men can initiate divorce by pronouncing the repudiation formula three times: "I divorce you." 86

Divorce can be classified into five major categories: 1) talaq; 2) talaq altafwid; 3) khul or mubaraab; 4) lian and faskh and; 5) apostasy. In the first category, talaq, is the husband's right to divorce his wife by making a pronouncement that the marriage is dissolved. ${ }^{87}$ The husband can state his desire to repudiate his wife by using phrases such as: "Thou art divorced," or "I have divorced thee," or "I divorce my wife forever and render her forbidden for me." The Hanafi school regards the act of divorce to be one of great gravity that whether the repudiation formula used as a jest, a threat, in drunkenness, or even under compulsion, it is still considered to be valid and effective. 88 Furthermore, a husband's act of divorce in Hanafi law is unregulated; a Muslim male who has attained puberty and is of sound mind has the right to divorce his wife without providing any reason. ${ }^{89}$ This gives the Muslim male an almost unilateral access to divorce his wife. The wife, on the other hand, is generally entitled to divorce her husband only in a court of law and only upon proof of the particular grounds specified by the statute. ${ }^{90}$ The second category of divorce is talaq al-tafwid or delegated divorce. While the husband has more access to divorce than his wife, the husband can give the wife a limited access to divorce when he expresses words such as "choose" or "divorce yourself." 91 This is based on the Qur'anic verse that states: "And women shall have rights similar to those against them, according to what is

${ }^{82}$ Qur'an 30:21.

83 Qur'an 2:187.

84 Esposito, Women in Muslim Family Law, 29.

85 Ibid.

86 Fatima Mernissi, Beyond the Veil: Male-Female Dynamics in Modern Muslim Society (Indianapolis, IN: Indiana University Press, 1987), 52. This does not mean however that the husband can render the divorce valid by pronouncing the repudiation formula three times in one occurrence. Such act of divorce is considered talaq al-bidah, disapproved divorce. See Esposito, Women in Muslim Family Law, 31-33.

${ }^{87}$ Ibid., 30.

88 Ibid.

${ }^{89}$ Ibid., 31.

90 Sally Baden, The Position of Women in Islamic Countries: Possibilities, Constraints and

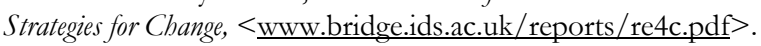

${ }^{91}$ Espsito, Women in Muslim Family Law, 33. 


\section{GENDER JIHAD}

equitable." 92 A khul divorce comes about through the common consent of the husband and wife. The Qur'an states:

And it is not lawful for you that ye take from women aught of that which ye have given them; except (in the case) when both fear that they may not be able to keep

the limits of Allah, in that case, it is no sin for either of them if the woman ransom herself (gives up something to her husband in exchange for her freedom)..$^{93}$

Under this method, the wife obtains the consent of the husband by paying him a sum of money. The husband may refuse to grant his consent at any price or demand an exorbitant amount for his consent; as a result, the wife may be unable to gain her liberty even through khul.94 Originally, khul was meant to be an equitable solution for separation. If the wife wishes to be separated from her husband, she can leave him as long as the wife returns the mahr. ${ }^{95}$ Yet, today, as a result of patriarchal jurisprudence, women are expected to pay more than their mahr in order to obtain divorce by khul. The situation has become so serious that at times it has resembled blackmail. Furthermore, the practice of requiring the woman to pay an exorbitant amount in order to release her from marriage is contradictory to Surah 2:29 since it clearly states that that the husband is not allowed to take back anything that he has given his wife. The payment in exchange for the wife's freedom is voluntary but required. The fourth category of divorce is brought about by judicial process. This can be either through lian (mutual oath swearing) or faskh (annulment). Under the first type, the husband accuses his wife of adultery. The wife has the right to counter testimony and file a suit to bring about the retraction of her husband's accusation. Once the woman has filed a countersuit, the husband is not allowed to have sexual intercourse with the woman unless he retracts his claim. Lian is based on the following verses found in the Qur'an stating:

As for those who accuse their wives but have not witnesses except themselves; let the testimony of one of them be four testimonies, (swearing) by Allah that he is of those who speak the truth; and yet a fifth, invoking the curse of Allah on him if he is of those who lie. And it shall avert the punishment from her if she bear witness before Allah four times that the thing he said is indeed

\footnotetext{
${ }_{92}$ Qur'an 2:228.

${ }_{93}$ Qur'an 2:229.

94 Azizah Y. al-Hibri, Redefining Muslim Women's Roles in the Next Century, <http://www.karamah.org/docs/azizah_cq.pdf>.

95 This is usually translated as dowry. It would be wrong to regard mahr as bride price; it is not money that a man pays to obtain a wife. By providing mahr to the woman, she is assured that she will be secured financially.
} 
false, and a fifth (time) that the wrath of Allah be upon her if he spaketh the truth. ${ }^{96}$

The husband has to swear four times that he is speaking the truth because, otherwise, he will incur the wrath of God. This is a clear warning to husbands and wives not to slander against their spouses. If there is no resolution (as the judge will try to seek an agreement between both parties), the court will dissolve the marriage. Faskh (annulment) occurs when the wife makes a petition to dissolve the marriage. In contrast, the husband is not required by law to cite reasons to validate his repudiation of his wife. ${ }^{97}$ The Maliki school allows a wife to divorce her husband on any of the following grounds ${ }^{98}$ :

1. cruelty

2. refusal or inability to maintain her

3. desertion or,

4. serious disease or ailment that would make a continuance of the marriage harmful to the wife.

Divorce by apostasy occurs when the husband or wife renounces the Islamic faith. Because this condition provides a possible opportunity for wives to dissolve their marriage, there are cases in which women claimed to have committed apostasy in order to free themselves from their husbands. ${ }^{99}$

\section{Conflict Resolution: An Islamic Solution}

Much of "oppressive" Muslim practices are not based on the religion itself but on the socio-political aspect of most Muslim countries; a resolution must be made with this in mind. A quick overview of the Muslim world will show that the oppressive practices are cultural. The problems facing a Pakistani woman may be different from her Malaysian, Indonesian, Arabian, Lebanese, etc. sisters. It is, then, important to unmask these practices which are assumed to be within the Islamic laws, and reveal them for what they really are: that they are neither divine nor condoned by the Divine. ${ }^{100}$

The Fourth World Conference on Women in Beijing and Houairou (1995) was a defining moment for Muslim women studies; it introduced two radical schools of thought: the first school of thought argued that the Shariah was outmoded and should be discarded in favor of a modern western secular

${ }^{96}$ Qur'an 24:6-9. Surab 4:20-21 also states: "And if ye wish to exchange one wife for another and ye have given unto one of them a sum of money (however great), take nothing from it. Would ye take it by the way of calumny and open wrong? How can ye take it (back) after one of you hath gone in unto the other, and they have taken a strong pledge from you?"

${ }^{97}$ Esposito, Women in Muslim Family Law, 35.

${ }^{98}$ Ibid.

${ }^{99}$ Ibid., 35-36.

100 al-Hibri, "Deconstructing Jurisprudence in Islamic Law," 221. 


\section{GENDER JIHAD}

model; while the second school of thought denied any problems existing Shari'ah laws. ${ }^{101}$ The first school is radical because it thinks that the Shari'ab is the problem, because it was modeled in the seventh century Arab society and that it cannot cope up with the changes of a fast-paced world. It views the West as modern and wants to pattern itself after it by applying Western theories on legal and social issues. The second school, on the other hand, is suspicious of the West and rejects all things western because it rejects Western political/cultural hegemony. ${ }^{102}$ The emergence of a third school steers away from the extremism of the first two schools. The third school of thought aims to engage in ijtibad; it wants to discover an authentic dialectic of transformation based on its indigenous historical context and the world of the twenty-first century. ${ }^{103}$ Unlike the first two schools of thought, it neither denies that there is a problem within the Shari'ah (or at least the interpretations of it), nor does it want to resort to the West for quick solutions. Rather, it aims to discover within itself an authentic dialogue with the Shariab in the twenty-first Weltanschaunng. ${ }^{104}$ Recent Islamic scholars such as Azizah al-Hibri and Amina Wadud ${ }^{105}$ are moving along this trend.

The institution of ijtihad provides room for interpretation. Ijtihad is critical thinking based on disciplined but independent reasoning. ${ }^{106}$ It means while the Qur'an is final and eternal, the interpretations of it are not; there is a need to challenge the interpretations of literalist-exclusivists and come up with an interpretation that supports equity among both genders. Such an interpretation is faithful to the Qur'an and the teachings of the Prophet Muhammad.

It is interesting to note the relation between jihad and ijtihad. Etymologically, both terms come from the root word ja-ha-da, which means "to strive" or "to exert."107 This is contained in the Qur'an: "And those who strive in our (cause),--We will certainly guide them to our Paths: For verily Allah is with those who do right. (29:69)." Gender jihad is a struggle to exorcise our sexist thinking through engaging in a progressive and critical interpretation of

101 Azizah al-Hibri, "Islamic Jurisprudence" in A Companion to Feminist Philosophy, ed. by Alison M. Jaggar and Iris Marion Young (Oxford: Blackwell Publishers, 1998), 541.

102 According to a Muslim feminist, Leila Ahmed, the Islamist adoption of the hijab, for example, is now an issue of cultural identification. According to her, the hijab goes gone beyond its "original" (or intended meaning) and has come to mean a distinction of the Western world, i.e. If the West is unveiled and to be veiled is to be Muslim.

103 Al-Hibri, "Islamic Jurisprudence," 541-542.

104 This means reading bebind and in front of the text. The first half allows one to specify the context of the Qur'anic revelations and the second to "distill" their moral principles so as to make them applicable today. To be able to read the Qur'an in the present weltanschauung is what makes the Qur'an timeless and timely and hence, a living text. See Melanie P. Mejia, $A$ Ricoeurian Reading of the Person, Sex and Gender in the Qur'an (Manila: Unpublished Masteral Thesis in Philosophy, UST Graduate School, 2007).

105 See Amina Wadud, Qur'an and Woman: Rereading the Sacred Text from a Woman's Perspective (New York: Oxford University Press, 1999).

106 Omid Safi (ed.), Progressive Muslims: On Justice, Gender and Pluralism (Oxford: Oneworld Publications, 2003), 8.

107 Ibid. 
Islam (ijtihad). ${ }^{108}$ This is a jihad that each and every Muslim must partake of. The patriarchal ideology in Islamic society came out of a distorting of the teachings of Islam to legitimate. Friedrich Nietzsche, a German philosopher, writes:

The worst readers are those who behave like plundering troops: they take away a few things they can use, dirty and confound the remainder, and revile the whole. 109

It is when we challenge that patriarchal ideology that overarches Islamic society through careful analysis of Islamic principles, practices and jurisprudence that we fulfill our duty of ijtihad. A big problem presents itself at this point. To critically examine Islamic jurisprudence and partake in jitibad, a woman must be familiar with usul al-figh (Islamic jurisprudence and its basic principles of reasoning). ${ }^{110}$ This is difficult to satisfy because over the centuries, women have been denied access to the field of Shari'ah. Thus, education plays a big part in empowering Muslim women. Education and knowledge is emphasized by Islam. As a matter of fact, the first word revealed to Muhammad was "read." 11 The prophet even stated that education is a duty (fardb) upon all Muslims (whether male or female). ${ }^{112}$

The history of Islam reveals that women were educated together with men. There are even reports that some of the most famous male scholars and jurists were educated by women. There are even cases where women would enter into debates regarding the interpretation of the Qur'an. A famous story relates about a debate between caliph Omar and an unknown woman. According to the story, the caliph wanted to put limits on the amount of mahr ${ }^{113}$ a woman may demand from her would-be husband. A Muslim woman vehemently objected and cited a passage from the Qur'an supporting her argument. Omar immediately backed out and admitted this error. This is just one story that reveals to us that women during the early Islamic stages were educated not only in literature and art but in jurisprudence as well. Reeducation should be introduced in a well-conceived manner and synchronized with plan to raise popular consciousness and create a new consensus. ${ }^{114}$

108 Ibid.

${ }^{109}$ Friedrich Nietzsche, Human, All Too Human tr. Walter Kaufmann, R. J. Hollingdale, Paul V. Cohn, <http://www.geocities.com/thenietzschechannel/mom.htm $>$ (30 December 2004).

110 Al-Hibri, Islam, Law and Custom.

111 See Qur'an 96:1-5.

112 Al-Hibri, Islam, Law and Custom.

113 The mahr is a requirement imposed by God upon men as a sign of their serious intention and commitment for the woman. It is a (financial) assurance for the woman in case she gets divorced or widowed. According to Islam, the mahr is the woman's alone; the husband has no access to the woman's mahr even if he is bankrupt and it can be used however she sees fit.

114 Al-Hibri, "Deconstructing Patriarchal Law," 225. 


\section{GENDER JIHAD}

\section{Conclusion}

In understanding violence and oppression (of Muslim women), a study of the dynamics of power must be undertaken. Power is not a property or an attribute; it is a relation. ${ }^{115}$ It requires a power sender, who by virtue of position and/or other resources, is able exercise effective power over another, called the power receiver. ${ }^{116}$ Power is dynamic; one does not have a monopoly of power because it flows from one person or institution to another. Understood in this sense, Muslim feminist works must focus on the dynamics of power relations in order to propose an effective solution towards their problems.

Gender equity and women oppression in Muslim society is an issue of understanding invisible power relations; it cannot be solved at this level but must be brought down to the level of a problem. There are subtopics and problems within that need to be addressed first before coming up with a resolution. This is just to say that there is no quick fix to this. One should not also hope to solve the problem by turning to the West for quick solutions. In the first place, the Muslims are suspicious about the Western world. Empowerment is the process of enabling or authorizing an individual to think, behave, take action and control work and decision making in autonomous ways. ${ }^{117}$ It is when one is able to think and act for himself/herself that $\mathrm{s} /$ he is empowered.

Empowering oneself is to be sure of oneself, to have a grounding and to value oneself as a person, as a woman and as a human being. To empower Muslim women, then, is not to force them to liberate themselves. The endeavor must come from themselves. More importantly, we must also understand that the road to empowerment is a process. ${ }^{118}$ We cannot just make abrupt changes because it will only worsen the situation.

Empowerment rests on three main concepts: direction, freedom and support. Direction is the charge or mission which will guide the person towards empowerment. Muslims should ask: what do I need? Do I want to liberate myself from my current status? What should I do? Freedom is being able to do something without being forced or compelled to act. This is also a fundamental Islamic teaching. Freedom will not work without providing or having resources. In this context, the only hope Muslims have towards empowerment is opening themselves towards challenging the patriarchal ideology that surrounds Islamic society today. However, they cannot do this alone since empowerment requires that one must be independent from the power sender. This is where the West can be of vital help. They can provide support by not aggravating the issues through one-sided media exposure and not imposing their will to "liberate" the Muslim women (against their own 1990), 92-93

115 See Michel Foucault History of sexuality: an introduction. (New York: Vintage Books,

116 Ibid.

117 Ibid.

118 This is in consonance with the Islamic principle of gradualism. 
will). In the end, the decision to empower or to remain with the status quo will be with the Muslims alone. Should there be any reforms made within Islam, it should be done the by Muslims and for the Muslims alone. 119

Department of Philosophy, Assumption College, Philippines

\section{References}

Ahmed, Leila, Women and Gender in Islam: Historical Roots of a Modern Debate (New Haven: Yale University Press, 1992).

al-Hamid Mutawalli, Abd, Mabadi Nizam al-Hukm Fi'l Islam (Alexandria 2nd ed., 1974).

al-Hibri, Azizah Y., Islam, Law and Custom: Redefining Women's Rights, $<$ http://www.karamah.org/docs/au_redefiningmwr.pdf $>$.

, Qur'anic Foundations of the Rights of Muslim Women in the Twenty-

First Century,

$<$ http://www.karamah.org/docs/azizah quranicfoundationsofmwr.pd $\underline{\mathrm{f}}>$.

Redefining Muslim Women's Roles in the Next Century, $<$ http://www.karamah.org/docs/azizah cq.pdf $>$.

, "A Study of Islamic Herstory: Or How Did We Ever Get into this Mess?," in Women's Studies International Forum, vol. 5 no. 1 (1982), 207-219.

"An Introduction to Muslim Women's Rights," in Windows of Faith ed. Gisela Webb (Syracuse University Press, 2000).

"Deconstructing Patriarchal Jurisprudence in Islamic Law: A

Faithful Approach," in Global Critical Race Feminism: An International

Reader, ed. by Adrien Katherine Wing (New York: New York University Press, 2000).

"Islam, Law and Custom: Redefining Women's Rights," in American University Journal of Law and Policy, vol. 12 no. 1(1997),

$<$ http://www.karamah.org/docs./au_redefiningmwr.pdf $>$

December 2004).

"Islamic Jurisprudence" in A Companion to Feminist Philosophy ed. Alison M. Jaggar and Iris Marion Young (Oxford: Blackwell Publishers, 1998).

- Islamic Constitutionalism and the Concept of Democracy, $<$ www.karamah.org/docs.azizah islamic constitutionalism.pdf $>$.

Baden, Sally, The Position of Women in Islamic Countries: Possibilities, Constraints and Strategies for Change, <http://www.bridge.ids.ac.uk/reports/re4c.pdf >.

Encyclopedia of Islamic Law: A Compendium of the Major Schools adapted by Laleh Bakhtiar (Chicago, IL: ABC International Group Inc., 1996).

119 Josephine A. Pasricha, "Feminism in the Afghani Women," Karunungan 19 (2002): 


\section{GENDER JIHAD}

Esposito, John L., Islam: the Straight Path, 3rd ed (New York: Oxford University Press, 1998).

Esposito, John L., Women in Muslim Family Law (Syracuse, NY: Syracuse University Press, 1982).

Foucault ${ }_{s}$ Michel, History of sexuality: an introduction. (New York: Vintage Books, 1990).

Goldhizer, Ignaz, Introduction to Islamic Theology and Law, trans. by Andras and Ruth Hamori (Princeton, NJ: Princeton University Press, 1981).

Khan, Qamaruddin, Status of Women in Islam (Bangalore, India: Sterling Publishers Pvt. Ltd., 1990).

Mejia, Melanie P., A Ricoeurian Reading of the Person, Sex and Gender in the Qur'an (Manila: Unpublished Masteral Thesis in Philosophy, UST Graduate School, 2007).

Mernissi, Fatima, Beyond the Veil: Male-Female Dynamics in Modern Muslim Society (Indianapolis, IN: Indiana University Press, 1987). The Veil and the Male Elite: A Feminist Interpretation of Women's Rights in Islam (Reading, MA: Addison-Wesley, 1991). ,Women and Islam: A Historical and Theological Inquiry, trans. by Mary Jo Lakeland (New Delhi: Kali for Women, 1991).

Nietzsche, Friedrich, Human, All Too Human tr. Walter Kaufmann, R. J. Hollingdale, Paul V. Cohn, $<\underline{\text { http://www.geocities.com/thenietzschechannel/mom.htm }>\quad(30}$ December 2004).

Pasricha, Josephine A., "Feminism in the Afghani Women," Karunungan 19 (2002). 